\title{
Climate response of tree-ring width in Larix sibirica growing in the drought-stressed forest-steppe ecotone of northern Mongolia
}

\author{
Choimaa Dulamsuren • Markus Hauck • \\ Hanns Hubert Leuschner • Christoph Leuschner
}

Received: 16 March 2010 /Accepted: 10 June 2010 / Published online: 7 April 2011

(C) The Author(s) 2011. This article is published with open access at Springerlink.com

\begin{abstract}
- Introduction Siberian larch (Larix sibirica) has its southern distribution limit in Mongolia in an area of rapidly rising temperatures. Direct effects of climate on tree-ring formation due to drought stress or indirect effects via the control of insect herbivore populations are little studied.

- Methods The hypotheses were tested that stem increment of Siberian larch is reduced by (1) drought during the growing season and (2) high snow cover, as the latter is thought to protect hibernating herbivores, including gypsy moth (Lymantria dispar).

- Results Tree-ring width increases with decreasing summer temperature, increasing precipitation during the growing season and decreasing winter precipitation.

- Conclusions The susceptibility of stem wood formation to drought during the growing season suggests that a future climate warming will decrease productivity of Siberian larch, thus affecting its existence within the forest-steppe ecotone of Mongolia. Narrow tree rings in years following winters with
\end{abstract}

Handling Editor: Gilbert Aussenac

Electronic supplementary material The online version of this article (doi:10.1007/s13595-011-0043-9) contains supplementary material, which is available to authorized users.

Ch. Dulamsuren $\cdot$ M. Hauck $(\bowtie) \cdot$ C. Leuschner Department of Plant Ecology, Albrecht von Haller Institute of Plant Sciences, University of Göttingen,

Untere Karspüle 2,

37073 Göttingen, Germany

e-mail: mhauck@gwdg.de

H. H. Leuschner

Department of Palynology and Climate Dynamics,

Albrecht von Haller Institute of Plant Sciences,

University of Göttingen,

Untere Karspüle 2,

37073 Göttingen, Germany low snowfall support the hypothesis that winter precipitation exerts an indirect effect on the growth of Siberian larch by controlling the survival rates of gypsy moth eggs.

Keywords Forest-steppe ecotone - Global warming Larix sibirica $\cdot$ Lymantria dispar $\cdot$ Tree-ring analysis

\section{Introduction}

The southern distribution limit of the vast Siberian taiga in the northern Mongolian forest-steppe ecotone is of special interest for the study of the impact of global warming on vegetation for four reasons: (1) late twentieth century warming in central and semiarid northeastern Asia significantly exceeded the global average (Batima et al. 2005); (2) northern Mongolia is a marginal habitat for forests already under the current climate, as tree growth is principally limited by drought (Gunin et al. 1999; Dulamsuren et al. 2009a); (3) the position of the forest-steppe borderline already migrated through Mongolia along with changing climate throughout the Holocene (Dinesman et al. 1989); and (4) the livelihood of Mongolia's rural population strongly depends on natural resources and is, in turn, influenced by climate-driven changes in vegetation patterns or productivity (Havstad et al. 2008). Even the main tree species in Mongolia's forest-steppe ecotone, Siberian larch (Larix sibirica Ledeb.), covering $80 \%$ of the country's forested area (Tsogtbaatar 2004), regularly suffers from drought stress (Dulamsuren et al. 2009a), shows reduced stem growth (Dulamsuren et al. 2010a), and has difficulties to regenerate in that area (Dulamsuren et al. 2008, 2010b; Hauck et al. 2008).

To assess the potential impact of global warming on the performance of Siberian larch forests in Mongolia, it is 
necessary to know which climate parameters exert an influence on tree growth. We, therefore, analyzed the impact of the seasonal and interannual variation of temperature and precipitation on tree-ring width in Siberian larch in the western Khentey Mountains, an area where weather recording started in the early 1960s. Since summer drought was shown to result in drought stress in Siberian larch of the western Khentey Mountains (Dulamsuren et al. 2009a) and larch trees show reduced stem growth since the 1950s (Dulamsuren et al. 2010a), we tested the hypothesis that high summer temperatures and low summer precipitation are correlated with narrow tree rings.

In addition to climate parameters which may exert a direct physiological effect on water relations, photosynthesis, and wood formation, indirect effects of climate on tree growth should be considered. Such indirect effects include the impact of herbivores or pathogens. Gypsy moth (Lymantria dispar L.) is a major pest in the forest-steppe ecotone of Mongolia, which has the potential to reduce tree-ring widths in Siberian larch (Ghent and Onken 2004; Hauck et al. 2008; Dulamsuren et al. 2010c). Since the eggs of gypsy moth are susceptible to severe frost (Waggoner 1985), we also tested the hypothesis that winter temperatures are inversely correlated with tree-ring width.

Increasing attention has recently been paid to the fact that climate-growth relationships can differ between the individual trees within one and the same stand (Wilmking et al. 2004). Several reasons may cause such divergent behavior, including genetic differences within the tree population or the smallscale variation of site parameters. Carrer and Urbinati (2004) additionally showed the existence of age-dependent variation in the response of tree-ring width on climate. We therefore distinguished three different age classes and between trees growing directly at the forest edge to the steppe or at the forest interior to test the hypotheses that the position along the forest-steppe ecotone and tree age influence the correlation of tree-ring width with climate parameters.

\section{Materials and methods}

\subsection{Study area}

Field work was carried out in the western Khentey Mountains, northern Mongolia, Mandal county (Mandal somon) near Khonin Nuga Research Station (49 $04^{\prime} 48^{\prime \prime}$ N, 107 $17^{\prime} 15^{\prime \prime}$ E), located $130 \mathrm{~km}$ north of Ulan Bator in the valley of the River Eroo, a tributary of the Orkhon River. Elevation of the study area ranges from $900 \mathrm{~m}$ in the river valleys up to $1,600 \mathrm{~m}$ asl on the mountain tops. Geologically, the Khentey mainly consists of Proterozoic and Paleozoic rocks, especially of granite. Permafrost is found under forests on north-facing slopes. Study sites were located near Khonin Nuga Research
Station on northwest-facing slopes of the Sharlan Valley $\left(49^{\circ} 6^{\prime} \mathrm{N}, 107^{\circ} 19^{\prime} \mathrm{E}\right.$; in the following called site $\left.\mathrm{A}\right)$ at an elevation of $1,010-1,072 \mathrm{~m}$, Mt. Bayantogol $\left(49^{\circ} 5^{\prime} \mathrm{N}\right.$, $107^{\circ} 17^{\prime} \mathrm{E}$; site B) at $1,020-1,120 \mathrm{~m}$, and Mt. Baziin Am $\left(49^{\circ} 3^{\prime} \mathrm{N}, 107^{\circ} 15^{\prime} \mathrm{E}\right.$; site C) at $990-1,090 \mathrm{~m}$.

The vegetation of the study area was currently surveyed by Dulamsuren et al. (2005a). Light taiga forests with L. sibirica dominate in the lower montane belt and partly in floodplains. Mountain forests of the lower montane belt are limited to the better water-supplied north-facing slopes, whereas southfacing slopes are covered with different types of montane meadow steppe, mountain steppe, and small savanna-like Ulmus pumila stands (Dulamsuren et al. 2005b, 2009b).

\subsection{Climate data}

The climate of the Khentey Mountains is characterized by the Asiatic anticyclone in winter, which typically has its center southwest of Lake Baikal and causes dry and cold winters. In summer, warm air masses from the south flow into northern Mongolia resulting in the formation of cyclones when they meet the cold air from Siberia (Dulamsuren and Hauck 2008). The nearest permanent weather station to the study area with a continuous dataset is located $87 \mathrm{~km}$ NW of Khonin Nuga Research Station (Station "Eroo") at an elevation of c. $900 \mathrm{~m}\left(49^{\circ} 48^{\prime} \mathrm{N}, 106^{\circ} 42^{\prime} \mathrm{E}\right)$. From this weather station, data of air temperature and precipitation are available since 1961 (Fig. 1) and were used as explanatory variables. Mean temperatures from 1961 to 2005 amounted to $-2.1 \pm 0.2^{\circ} \mathrm{C}$ for the whole year, $-27.4 \pm$ $0.5^{\circ} \mathrm{C}$ for January, and $18.7 \pm 0.2^{\circ} \mathrm{C}$ for July. Variation of mean temperature is higher in winter (mean January temperatures, -35.3 to $-17.0^{\circ} \mathrm{C}$ ) than in summer (July, 16.4 to $\left.22.3^{\circ} \mathrm{C}\right)$. Mean annual precipitation was $277 \pm$ $11 \mathrm{~mm}$. A marked precipitation peak in summer (Fig. 1)

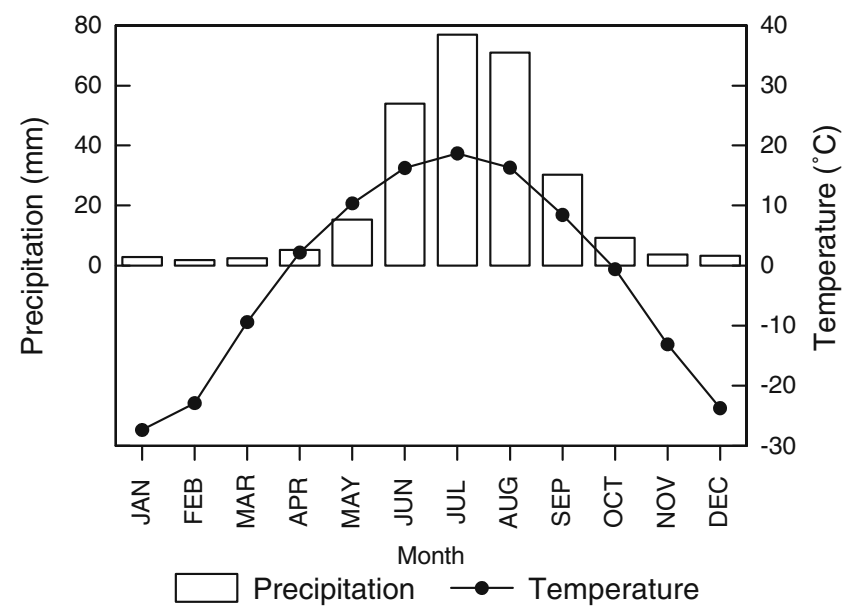

Fig. 1 Climatic diagram for Eroo $\left(49^{\circ} 48^{\prime} \mathrm{N}, 106^{\circ} 42^{\prime} \mathrm{E}, 900 \mathrm{~m}\right.$ asl). Mean monthly precipitation and temperatures were calculated for the period 1961 to 2005 
with $78 \pm 6 \mathrm{~mm}$ in July (but only $3 \pm 1 \mathrm{~mm}$ in January) is typical of the area (Dulamsuren and Hauck 2008).

\subsection{Wood core sampling and processing}

Wood cores were sampled from the trees of the three sites A, B, and C in September 2007. Six plots of $20 \mathrm{~m} \times 20 \mathrm{~m}$ were selected per site. They were located in minimum distances of $30 \mathrm{~m}$ from the forest line to the steppe and of $100 \mathrm{~m}$ from one another. In these plots, wood cores of 272 trees of $L$. sibirica were collected (Table 1) with an increment borer of $5 \mathrm{~mm}$ of the inner diameter. In addition to the trees growing inside the forest, single trees located immediately at the forest line were sampled each in one oblong plot per site. The length of these plots varied between 50 and $100 \mathrm{~m}$. The number of these additionally sampled trees amounted to 93 trees (Table 1). At $1 \mathrm{~m}$ above the ground, the borer was driven into the wood parallel to the contour lines of the mountain slopes to avoid compression wood. Annual tree-ring width was measured with a precision of $10 \mu \mathrm{m}$ on a movable object table (Lintab 5, Rinntech, Heidelberg, Germany), the movements of which are electronically transmitted to a computer system equipped with TSAP (Time Series Analysis and Presentation)-Win software (Rinntech). The light earlywood and the dark latewood were visually differentiated and separately measured.

\subsection{Evaluation of the tree-ring data}

Evaluation of tree-ring data was, like data recording, conducted with TSAP-Win software. Tree-ring series were controlled for missing rings and false rings during crossdating, as especially the failure of tree rings is not rare in the semiarid environment of Mongolia at the drought limit of forests. Crossdating was based on the use of two parameters: coefficient of agreement ("Gleichläufigkeit" [GL]; Eckstein and Bauch 1969) and (standard) $t$ values. The GL and $t$ values measure the similarity between tree-ring series in the high- and lowfrequency domain, respectively. Trees of the same site were pooled by calculating mean values of annual increment. Tree-ring series used for the calculation of means had GL values $>65 \%(P \leq 0.05)$ and $t$ values $>3$ ( $>6$ in c. $90 \%$ of the samples). Trend lines were calculated using moving 5-year averages, since we aimed at keeping as much of the interannual (high-frequency) variation as possible, because this is crucial for any climate-response analysis.

Standardized tree-ring series were used in correlation analyses with climate parameters. Standardization is principally achieved by dividing the observed tree-ring width $\left(w_{i}\right)$ through the expected annual increment. Finding the correct function for the age-related growth trend (for estimating the expected growth rate) is easier in semiarid environments, including our study area, than in regions with ample water supply, as the stand density in semiarid woodlands is relatively low and, thus, the individual trees are less influenced by changes in the stand structure than in dense and moist forests (Cook 1985). Therefore, the same type of standardization could be applied for all tree-ring series. The annual tree-ring index $\left(z_{i}\right)$ of year $i$ was calculated with the equation $\mathrm{z}_{\mathrm{i}}=100 \times\left(\mathrm{w}_{\mathrm{i}}-\mathrm{m}_{\mathrm{i}}\right) / \sum \mathrm{w}_{\mathrm{i}}$ with $m_{i}$ being the 5 -year moving average of year $i$. Three age classes were distinguished in the analyses including "old trees" with the
Table 1 Descriptive statistics of the sampled $L$. sibirica trees, including the number of sample trees $(N)$, mean tree-ring width, values of the expressed population signal (EPS), mean sensitivity and first-order auto correlation (arithmetic means \pm standard deviation)

$A, B, C$ site A, B, C. FI forest interior, $F E$ forest edge, $O$ old trees (cambial age $>90$ years), $M$ middle-aged trees (50 to 90 years), $Y$ young trees $(<50$ years $)$

Statistics: Duncan's multiple range test, $d f=367, P \leq 0.05$. Means with a common letter do not differ significantly

\begin{tabular}{llllll}
\hline Site & Number & Ring width $(\mathrm{mm})$ & EPS & Mean sensitivity & Autocorrelation \\
\hline A-FI-O & 22 & $1.50 \pm 0.50$ & 1.00 & $0.41 \pm 0.06 \mathrm{ab}$ & $0.73 \pm 0.08 \mathrm{abcd}$ \\
A-FI-M & 41 & $0.91 \pm 0.43$ & 1.00 & $0.38 \pm 0.08 \mathrm{abcd}$ & $0.79 \pm 0.10 \mathrm{ab}$ \\
A-FI-Y & 18 & $1.00 \pm 0.51$ & 1.00 & $0.39 \pm 0.07 \mathrm{abcd}$ & $0.70 \pm 0.14 \mathrm{cde}$ \\
A-FE-O & 12 & $1.50 \pm 0.26$ & 0.96 & $0.48 \pm 0.05 \mathrm{e}$ & $0.68 \pm 0.06 \mathrm{de}$ \\
A-FE-M & 10 & $2.20 \pm 0.65$ & 0.96 & $0.40 \pm 0.05 \mathrm{ab}$ & $0.70 \pm 0.05 \mathrm{cde}$ \\
A-FE-Y & 8 & $2.10 \pm 0.73$ & 0.94 & $0.37 \pm 0.04 \mathrm{abcdf}$ & $0.67 \pm 0.11 \mathrm{de}$ \\
B-FI-O & 32 & $1.17 \pm 0.41$ & 0.97 & $0.38 \pm 0.05 \mathrm{abcd}$ & $0.79 \pm 0.08 \mathrm{ab}$ \\
B-FI-M & 72 & $1.47 \pm 0.49$ & 0.99 & $0.36 \pm 0.06 \mathrm{acdf}$ & $0.78 \pm 0.08 \mathrm{abc}$ \\
B-FI-Y & 18 & $1.68 \pm 0.73$ & 0.96 & $0.34 \pm 0.07 \mathrm{cdfg}$ & $0.72 \pm 0.14 \mathrm{bcde}$ \\
B-FE-O & 0 & & - & - & - \\
B-FE-M & 19 & $1.93 \pm 0.50$ & 0.98 & $0.42 \pm 0.05 \mathrm{~b}$ & $0.70 \pm 0.09 \mathrm{cde}$ \\
B-FE-Y & 14 & $2.39 \pm 0.56$ & 0.95 & $0.41 \pm 0.06 \mathrm{ab}$ & $0.63 \pm 0.16 \mathrm{e}$ \\
C-FI-O & 19 & $1.04 \pm 0.20$ & 0.95 & $0.33 \pm 0.05 \mathrm{cdf}$ & $0.75 \pm 0.10 \mathrm{abcd}$ \\
C-FI-M & 4 & $1.57 \pm 0.47$ & 0.83 & $0.29 \pm 0.04 \mathrm{~g}$ & $0.80 \pm 0.07 \mathrm{a}$ \\
C-FI-Y & 46 & $1.48 \pm 0.59$ & 0.98 & $0.32 \pm 0.07 \mathrm{fg}$ & $0.80 \pm 0.07 \mathrm{ab}$ \\
C-FE-O & 9 & $1.53 \pm 0.36$ & 0.95 & $0.42 \pm 0.02 \mathrm{~b}$ & $0.68 \pm 0.10 \mathrm{de}$ \\
C-FE-M & 3 & $1.24 \pm 0.69$ & 0.71 & $0.38 \pm 0.05 \mathrm{abcd}$ & $0.68 \pm 0.03 \mathrm{de}$ \\
C-FE-Y & 18 & $1.87 \pm 0.83$ & 0.96 & $0.39 \pm 0.07 \mathrm{abd}$ & $0.70 \pm 0.08 \mathrm{cde}$ \\
\hline
\end{tabular}


oldest tree ring (at the sampling height of $1 \mathrm{~m}$ ) older than 90 years, "middle-aged trees" (oldest tree ring being between 50 and 90 years old), and "young trees" (oldest tree ring younger than 50 years old).

Tree-ring series were representative of the studied stand as shown by the calculation of the expressed population signal (EPS) using sums of squares of within-core variation and error sums of squares calculated in a two-way analysis of variance (ANOVA; Wigley et al. 1984). The EPS clearly exceeded the 0.85 threshold (Wigley et al. 1984), except for the few middle-aged trees available at site $\mathrm{C}$ (Table 1). Therefore, in contrast to all other tree-ring series, the reliability of these particular data from site $\mathrm{C}$ is limited.

Year-to-year variability of tree-ring width was expressed as mean sensitivity, as was the influence of the increment in the previous year on the increment of the current year as firstorder autocorrelation coefficient (Fritts 1976). Mean sensitivity and autocorrelation coefficients were calculated over the whole lifespan of each sample tree. Afterwards, mean values of these parameters were calculated over age classes and sites. These means were tested for statistical significance using Duncan's multiple range test, after testing for normal distribution with the Shapiro-Wilk test. These analyses and the abovementioned ANOVAs were calculated with SAS 6.04 software (SAS Institute Inc., Cary, NC, USA).

\subsection{Analysis of climate-growth relationships}

Relationships between climate parameters and tree-ring width were analyzed both with a multivariate approach using multiple regression analysis and a bivariate approach calculating Pearson's correlations coefficients. Bivariate correlations were calculated in addition to multiple regression analysis to show the positive or negative character of the influence of the individual climate parameters on tree-ring width. As the repeated analysis of the same dataset by multiple and bivariate regression analyses carries the inherent danger of increasing type I errors, results of the bivariate regression analyses are interpreted with caution if the relevant determinants do not occur in the multivariate models. Independent climate parameters in the multivariate analysis included quarterly and annual mean temperatures and mean precipitation of the current and the previous year. The bivariate analysis was restricted to quarterly and monthly climate values; months without any significant correlation are not displayed in the relevant figures. Tree-ring parameters (dependent variables) included total tree-ring width as well as the widths of earlywood and latewood. We refrained from dividing the data in two intervals for calibration and verification (Fritts et al. 1971; Fritts 1976), because the available series of climate data covers only 45 years. The renouncement of a verification period and the choice of relatively simple correlation statistics were also preferred by
Bräuning (1999), who had to deal with similarly short time series of climate data in Tibet. Trees which formed the oldest tree ring after 1961 were omitted from the analysis. Regression analyses were computed with SAS 6.04 software.

\section{Results}

\subsection{Descriptive statistics}

The tree-ring chronology from the western Khentey Mountains ranges over little more than 200 years (Fig. 2). In many cases, mean sensitivity is significantly higher in trees from the forest edge than in trees from the forest interior (Table 1). There is also a trend for lower first-order autocorrelation at the edge than in the interior of the forest, which is rarely significant, though. Mean sensitivity decreased with increasing autocorrelation in old interior trees from sites A $(r=-0.45, P=0.02)$ and $\mathrm{C}(r=-0.73, P=0.004)$ and in middle-aged interior trees from sites A $(r=-0.33, P=0.05)$ and $\mathrm{B}(r=-0.44, P<0.001)$. At the forest edge or in young trees, such relationship was lacking.

\subsection{Climate response}

High summer temperatures and low precipitation during the growing season are correlated with the occurrence of narrow tree rings. Analyzing the effect of climate on treering width separately for trees of different age groups, sites, distances to the forest edge and for width of the total tree ring, earlywood and latewood, summer temperature occurs in $36(71 \%)$ out of the 51 most significant regression models with three climate parameters and in 47 (92\%) regression models with four climate parameters (Table S1, available online at www.afs-journal.org). In a monthwise analysis, significant correlations with summer temperature

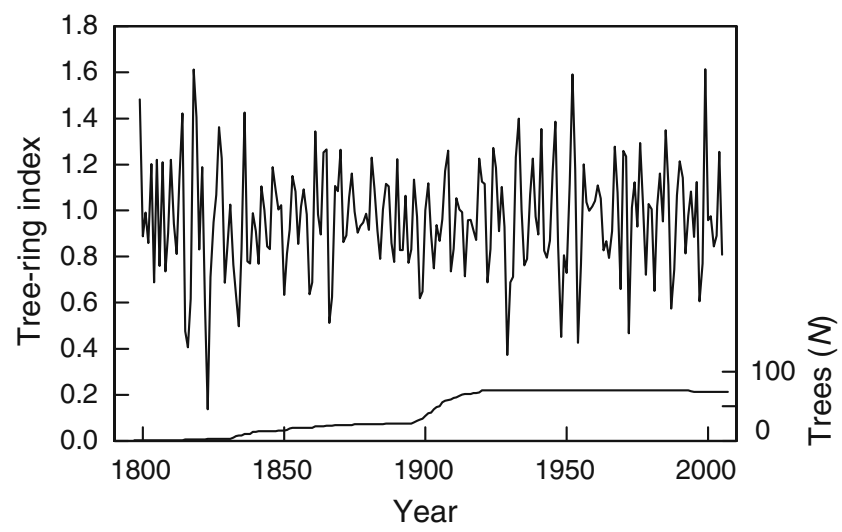

Fig. 2 Tree-ring chronology of Siberian larch calculated from all old trees (cambial age $>90$ years) growing in the forest interior in the western Khentey Mountains (sites A, B, and C) 
are found with June, July, and/or August temperature depending on the plot (Fig. 3, S1, S2), whereas significant correlations are lacking in the hottest, but simultaneously most rain-laden month, July (Fig. 1). Correlations with summer temperature occur more regularly if calculations are based on quarterly values (from June to August; Fig. S3 to S5). Precipitation during the growing season is correlated with tree-ring width in $45(88 \%)$ of the most significant regression models with three independent variables and in $48(94 \%)$ of the most significant models with four independent variables (Table S1). Mostly, these correlations refer to the precipitation at the end of the growing season in the year prior to tree-ring formation in September and October (Fig. 4, S6, S7) at a point in time when monthly precipitation is limited to $30 \mathrm{~mm}$ (September) or $<10 \mathrm{~mm}$ (October; Fig. 1). Summer precipitation (June to August) is only included in $10 \%$ of the regression models with three variables and in $14 \%$ of the models with four independent variables (Table S1). These correlations refer both to June and July and to the year of and prior to tree-ring formation (Fig. 4, S6, S7; Table S1). Correlation of tree-ring width with spring precipitation is negligible (Table S1).

Low snowfall in the winter before the growing season when the tree-ring is formed, or more rarely even in the winter before that winter, is correlated with wide tree rings
(Fig. 4, S6, S7). Nearly all most significant models with three $(49 ; 96 \%)$ or four $(47 ; 92 \%)$ independent climate parameters include winter precipitation (Table S1), which never exceeds $5 \mathrm{~mm}$ per month (Fig. 1). Winter temperature is not relevant to tree-ring formation (Fig. 3, S1, S2; Table S1).

No consistent pattern for an influence of tree age, the site or the plot position in the forest-steppe ecotone (forest edge vs. interior) on the correlations between tree-ring width and climate parameters is observed.

\section{Discussion}

The results support the hypothesis that drought periods during the growing season limit stem wood formation in Siberian larch. The negative influence of low precipitation and high summer temperatures match with low shoot water potentials, close to the point of zero turgor, measured during drought periods in trees of Siberian larch in the study area (Dulamsuren et al. 2009a). Furthermore, the finding agrees with the fact that Siberian larch has its drought limit in Mongolia (Gunin et al. 1999; Miehe et al. 2007). It is noteworthy that the minimum shoot water potentials in the study of Dulamsuren et al. (2009a)
Fig. 3 Response of tree-ring width to monthly mean temperatures of the year of and the year prior to tree-ring formation at site A (Pearson's productmoment correlation coefficients; $* P \leq 0.05)$. a, c, e Forest interior. $\mathbf{b}, \mathbf{d}, \mathbf{f}$ Forest edge. a, b Total tree-ring width. c, d Earlywood. e, f Latewood. Months without any significant correlation are omitted

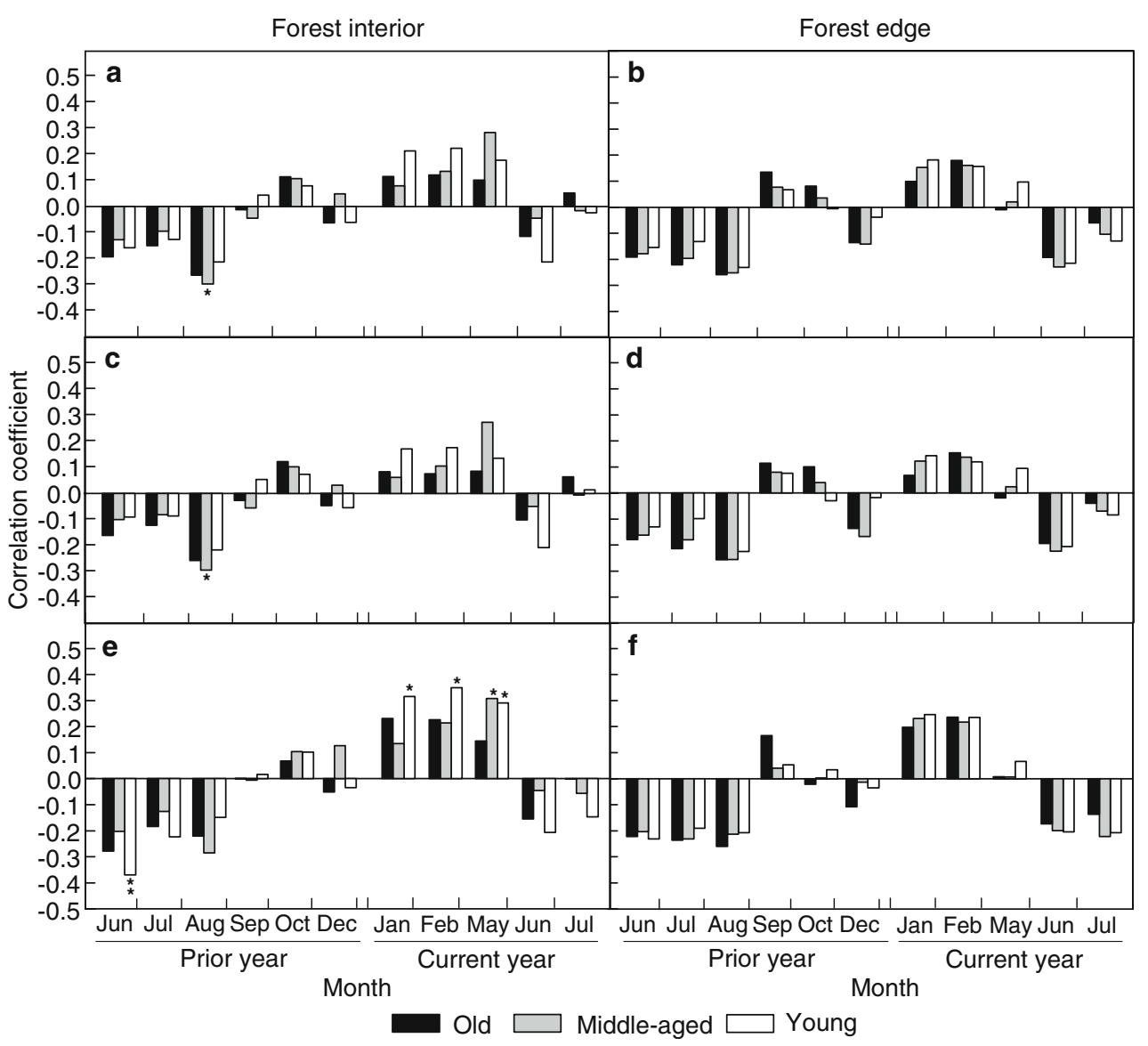


Fig. 4 Response of tree-ring width to monthly precipitation of the year of and the year prior to tree-ring formation at site A (Pearson's productmoment correlation coefficients; $\left.{ }^{*} P \leq 0.05\right)$. a, c, e Forest interior. $\mathbf{b}, \mathbf{d}, \mathbf{f}$ Forest edge. a, b Total tree-ring width. c, d Earlywood. e, f Latewood. Months without any significant correlation are omitted

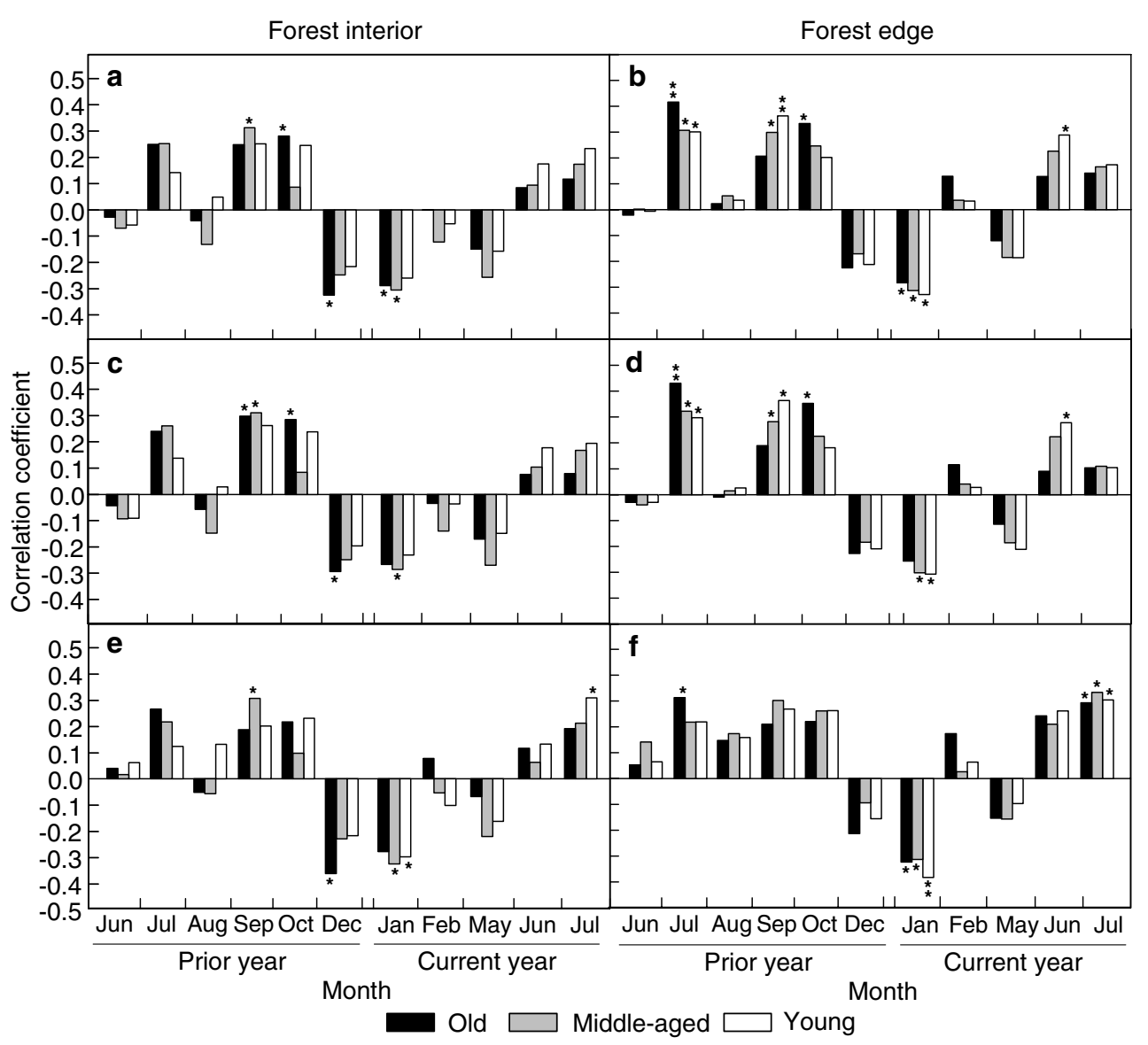

decreased throughout the growing season with a minimum in early fall. Similarly, Li et al. (2007b) found steadily decreasing $\delta^{13} \mathrm{C}$ values in needles of Siberian larch from June to late September in the Kherlen valley, northeastern Mongolia. The lack of recovery of the plant water status in fall despite significantly lower temperatures than in summer is attributable to the low fall precipitation (Fig. 1). Li et al. (2007a) showed by the analysis of $\delta^{18} \mathrm{O}$ and $\delta \mathrm{D}$ (deuterium) signatures in precipitation, soil, and shoot water that forests of Siberian larch in northern Mongolia primarily depend on surface water from the current precipitation. Carbon assimilated at the end of the growing season is apparently used for wood formation in the following growing season, explaining the increase of tree-ring width with increasing precipitation in September and even October of the year prior to tree-ring formation. Siberian larch is photosynthetically active in the study area until late September or early October (Dugarjav 2006; Li et al. 2007b; Dulamsuren et al. 2009a), though there is considerable interannual variation due to the highly variable climate in northern Mongolia (Nandintsetseg et al. 2007; Dulamsuren and Hauck 2008).

Decreasing tree-ring width with increasing winter precipitation supports the hypothesis that the snow cover protects herbivores of Siberian larch hibernating on the ground from frost damage and thereby reduces the annual wood formation in the subsequent growing seasons. Gypsy moth is the most common and most detrimental herbivore of Siberian larch in northern Mongolia (Hauck et al. 2008). Heavily infested larch trees were shown to show strongly reduced tree-ring widths for at least 2 years after the gypsy moth invasion (Dulamsuren et al. 2010c). Gypsy moth preferentially oviposits on rock outcrops on south-facing steppe slopes near forest edges (Hauck et al. 2008). Eggs of gypsy moth were shown to die at steady temperatures below $-26^{\circ} \mathrm{C}$ (Waggoner 1985) and therefore benefit from insulation by snow (Nealis et al. 1999; Andresen et al. 2001). Freezing rapidly kills the eggs below the $-26^{\circ} \mathrm{C}$ threshold, as all gypsy moth eggs used in a laboratory experiment died within $46 \mathrm{~h}$ at $-26^{\circ} \mathrm{C}$, but already within $20 \mathrm{~min}$ at $-27.8^{\circ} \mathrm{C}$ (Waggoner 1985). Periods with very low winter temperatures are characteristic of the Mongolian forest-steppe ecotone. Dulamsuren and Hauck (2008) measured minimum air temperatures (at $1.5 \mathrm{~m}$ above the ground) of $-43^{\circ} \mathrm{C}$ on south-facing slopes of the western Khentey Mountains in immediate proximity to egg masses of gypsy moth. Periods with daily minima below $-26^{\circ} \mathrm{C}$ occur for weeks, whereas intervals where even the daily maximum temperature does not exceed this value are 
limited to single or a few consecutive days. Mongolia's low winter temperatures and the extremely low snowfall (total precipitation from October to April in the study area is $<30 \mathrm{~mm}$; Fig. 1) rule out that the high significance of winter precipitation for tree-ring width in the regression models is directly connected to carbon assimilation or water relations in L. sibirica. Snow cover plays no role at reducing frost damage in near-surface roots (Korotaev 1994), as otherwise tree-ring width should increase, not decrease, with increasing winter precipitation. Limitation of root activity in spring by persistent snow packs as postulated for Larix gmelinii stands in central Siberia (Kujansuu et al. 2007) is not to be expected in Mongolia given the low amount of winter precipitation.

Trends for higher mean sensitivity and lower autocorrelation in tree-ring series from the forest edge than the forest interior show that trees at the edge to the steppe are exposed to more strongly varying climatic conditions than interior trees. The regression analyses, however, suggest that wood formation in Siberian larch is influenced by drought during the growing season and snow cover in winter largely irrespective of their distance from the forest line to the steppe, their age or the study site. Both direct (drought years) and indirect (climateinfluenced herbivore invasions) climate effects can exert an enduring effect on carbon allocation in larch trees. This is suggested by the numerous correlations of tree-ring width found with climate parameters from the year prior tree-ring formation (Kujansuu et al. 2007).

\section{Conclusion}

Our data suggest that both drought periods during the growing season and winter snow pack influence wood formation in Siberian larch in the northern Mongolian forest-steppe ecotone across a wide range of habitats differing in microclimate (as assessed by the comparative study of trees from the forest interior and the edge to the steppe) and age classes. Aridity has steadily increased during the late twentieth and the early twenty-first centuries in the western Khentey Mountains (Dulamsuren et al. 2010a). The results of the regression analyses confirm that growth declines observed in Siberian larch in the western Khentey since the mid-twentieth century are attributable to increasing drought during the growing season as already established by Dulamsuren et al. (2010a). The significance of gypsy moth invasions will probably also increase due to climate warming, which may, among others, cause higher survival rates in winter (Logan et al. 2003). Thus, it is probable that global warming will increasingly deteriorate the growth conditions of Siberian larch in the northern Mongolian forest-steppe ecotone both by causing drought stress and by triggering more frequent gypsy moth outbreaks.
Acknowledgments The study was supported by a grant of the German Science Foundation (Deutsche Forschungsgemeinschaft) to Ch. Dulamsuren (Du 1145/1-2). We are thankful to Prof. Dr. Michael Mühlenberg (Center of Nature Conservation, University of Göttingen) to make the facilities of Khonin Nuga Research Station (a biological field station jointly run by the University of Göttingen and the National University of Mongolia, Ulan Bator) available to the authors.

Open Access This article is distributed under the terms of the Creative Commons Attribution Noncommercial License which permits any noncommercial use, distribution, and reproduction in any medium, provided the original author(s) and source are credited.

\section{References}

Andresen JA, McCullogh DG, Potter BE, Koller CN, Bauer LS, Lusch DP, Ramm CW (2001) Effects of winter temperatures on gypsy moth egg masses in the Great Lakes region of the United States. Agric For Meteorol 110:85-100

Batima P, Natsagdorj L, Gombluudev P, Erdenetsetseg B (2005) Observed climate change in Mongolia. Assessments of Impacts and Adaptations of Climate Change Workings Papers No. 12, International START Secretariat Washington DC, $26 \mathrm{p}$

Bräuning A (1999) Zur Dendroklimatologie Hochtibets während des letzten Jahrtausends. Diss Bot 312:1-164

Carrer M, Urbinati C (2004) Age-dependent tree-ring growth responses to climate in Larix decidua and Pinus cembra. Ecology $85: 730-740$

Cook ER (1985) A time series analysis approach to tree ring standardization. $\mathrm{PhD}$ thesis, University of Arizona, Tucson, $171 \mathrm{p}$

Dinesman LG, Knyazev AV, Kiseleva NK (1989) History of the steppe ecosystems of the Mongolian People's Republic. Nauka, Moscow, $214 \mathrm{p}$

Dugarjav Ch (2006) Larch forests of Mongolia. Bembi san, Ulan Bator, $309 \mathrm{p}$

Dulamsuren Ch, Hauck M (2008) Spatial and seasonal variation of climate on steppe slopes of the northern Mongolian mountain taiga. Grassl Sci 54:217-230

Dulamsuren Ch, Hauck M, Mühlenberg M (2005a) Vegetation at the taiga forest-steppe borderline in the western Khentej Mountains, northern Mongolia. Ann Bot Fenn 42:411-426

Dulamsuren Ch, Hauck M, Mühlenberg M (2005b) Ground vegetation in the Mongolian taiga forest-steppe ecotone does not offer evidence for the human origin of grasslands. Appl Veg Sci 8:149-154

Dulamsuren Ch, Hauck M, Mühlenberg M (2008) Insect and small mammal herbivores limit tree establishment in northern Mongolian steppe. Plant Ecol 195:143-156

Dulamsuren Ch, Hauck M, Bader M, Osokhjargal D, Oyungerel Sh, Nyambayar S, Runge M, Leuschner C (2009a) Water relations and photosynthetic performance in Larix sibirica growing in the foreststeppe ecotone of northern Mongolia. Tree Physiol 29:99-110

Dulamsuren Ch, Hauck M, Nyambayar S, Bader M, Osokhjargal D, Oyungerel Sh, Leuschner C (2009b) Performance of Siberian elm (Ulmus pumila) on steppe slopes of the northern Mongolian mountain taiga: drought stress and herbivory in mature trees. Environ Exp Bot 66:18-24

Dulamsuren Ch, Hauck M, Leuschner C (2010a) Recent drought stress leads to growth reductions in Larix sibirica in the western Khentey, Mongolia. Global Change Biology 16:3025-3035

Dulamsuren Ch, Hauck M, Khishigjargal M, Leuschner HH, Leuschner C (2010b) Diverging climate trends in Mongolian taiga forests influence growth and regeneration of Larix sibirica. Oecologia 163:1091-1102 
Dulamsuren Ch, Hauck M, Leuschner HH, Leuschner C (2010c) Gypsy moth-induced growth decline of Larix sibirica in a foreststeppe ecotone. Dendrochronologia 28:207-213

Eckstein D, Bauch J (1969) Beitrag zur Rationalisierung eines dendrochronologischen Verfahrens und zur Analyse seiner Aussagesicherheit. Forstwiss Centbl 88:230-250

Fritts HC (1976) Tree rings and climate. Academic, London, $567 \mathrm{p}$

Fritts HC, Blasing TJ, Hayden BP, Kutzbach JE (1971) Multivariate techniques for specifying tree-growth and climate relationships and for reconstructing anomalies in paleoclimate. J Appl Meteorol 10:845-864

Ghent JH, Onken AH (2004) Trip report on assistance to Mongolian Ministry for Nature and Environment for the control of forest defoliators. FAO Project TCP/MON/2902, Asheville, NC, 8 p

Gunin PD, Vostokova EA, Dorofeyuk NI, Tarasov PE, Black CC (1999) Vegetation dynamics of Mongolia. Kluwer, Dordrecht, $238 \mathrm{p}$

Hauck M, Dulamsuren Ch, Heimes C (2008) Effects of a gypsy moth invasion on the performance of Larix sibirica in a forest-steppe ecotone of northern Mongolia. Environ Exp Bot 62:351-356

Havstad KM, Herrick J, Tseelei E-A (2008) Mongolia's rangelands: is livestock production the key to the future? Front Ecol 8:386-391

Korotaev AA (1994) Untersuchungen zur Frostresistenz von Baumwurzeln. Forstarchiv 65:93-95

Kujansuu J, Yasue K, Koike T, Abaimov AP, Kajimoto T, Takeda T, Tokumoto M, Matsuura Y (2007) Climatic responses of tree-ring widths of Larix gmelinii on contrasting north-facing and southfacing slopes in central Siberia. J Wood Sci 53:87-93

Li S-G, Romero-Saltos H, Tsujimura M, Sugimoto A, Sasaki L, Davaa G, Oyunbaatar D (2007a) Plant water sources in the cold semiarid ecosystem of the upper Kherlen river catchment in Mongolia: a stable isotope approach. J Hydrol 333:109-117

Li S-G, Tsujimura M, Sugimoto A, Davaa G, Oyunbaatar D, Sugita M (2007b) Temporal variation of $\delta^{13} \mathrm{C}$ of larch leaves from a montane boreal forest in Mongolia. Trees 21:479-490

Logan JA, Régnière J, Powell JA (2003) Assessing the impacts of global warming on forest pest dynamics. Front Ecol Environ 1:130-137

Miehe G, Schlütz F, Miehe S, Opgenoorth L, Cermak J, Samiya R, Jäger EJ, Wesche K (2007) Mountain forest islands and Holocene environmental changes in Central Asia: a case study from the southern Gobi Altay, Mongolia. Palaeogeogr Palaeoclimatol Palaeoecol 250:150-166

Nandintsetseg B, Greene JS, Goulden CE (2007) Trends in extreme daily precipitation and temperature near Lake Hövsgöl, Mongolia. Int J Climatol 27:341-347

Nealis VG, Roden PM, Ortiz DA (1999) Natural mortality of the gypsy moth along a gradient of infestation. Can Entomol 131:507-519

Tsogtbaatar J (2004) Deforestation and reforestation needs in Mongolia. For Ecol Manage 201:57-63

Waggoner PE (1985) How gypsy moth eggs freeze. Agric For Meteorol 36:43-53

Wigley TML, Briffa KR, Jones PD (1984) On the average value of correlated time series, with applications in dendroclimatology and hydrometeorology. J Clim Appl Meteorol 23:201-213

Wilmking M, Juday GP, Barber VA, Zald HS (2004) Recent climate warming forces contrasting growth responses of white spruce at treeline in Alaska through temperature thresholds. Glob Chang Biol 10:1-13 